\title{
REVIEW
}

\section{Serum tumour markers in lung cancer: history, biology and clinical applications}

\author{
D. Ferrigno*, G. Buccheri*, A. Biggi**
}

Serum tumour markers in lung cancer: history, biology and clinical applications. D. Ferrigno, G. Buccheri, A. Biggi. CERS Journals Ltd 1994.

ABSTRACT: The association of biological markers with cancer has been recognized for many decades. Current interest in markers for cancer arose in the mid 1960s, with the discoveries of alpha-fetoprotein and carcinoembryonic antigen. They were called oncofetal proteins, because of their presence in high concentrations during embryonic development, their virtual disappearance in the neonatal period, and their reappearance with cancers of specific cell types. Essentially, any molecular species may be produced in abnormal amounts or under abnormal circumstances by a tumour, and thereby become useful as a tumour marker.

Several tumour markers have been studied in lung cancer. Unfortunately, none of these appear to be sufficiently sensitive and specific to be reliable for screening and diagnostic purposes. However, there is a body of evidence which proves that at least some of these substances may be useful in the evaluation of the course and prognosis of the disease.

This review presents data concerning the most studied and interesting tumour markers in lung cancer.

Eur Respir J., 1994, 7, 186-197.

Tumour markers (TMs) are substances, usually of peptide nature, secreted by tumour cells. These substances are normally absent in the serum (or present in very low concentrations), since they are not secreted (or are secreted in very small amounts) by normal cells. COOMBES and co-workers [1, 2] defined the potential clinical applications of a tumour marker. It should: 1) facilitate the early diagnosis of tumour; 2) offer a guide for the evaluation of prognosis; 3) help in selecting patients for adjuvant chemotherapy; and 4) help in assessing the response to therapy and in diagnosing early relapses.

Moreover, the serum level of an ideal marker should: 1) increase pathologically in the presence of a neoplasm (high sensitivity); 2) not increase in the absence of neoplasms (high specifity); 3) relate to tumour burden and metastatic spread; 4) change in accordance with the clinical evolution, reflecting the current status of disease; or, better, 5 ) anticipate clinical changes, e.g. indicating the presence of relapse before it becomes obvious at a clinical level.

List of abbreviations: $\mathrm{ACTH}=$ adrenocorticotropic hormone; $\mathrm{ADH}=$ antidiuretic hormone; $\mathrm{BN}=$ bombesin; $\mathrm{CA}-19-9=$ carbohydrate antigenic determinant 19-9; $\mathrm{CEA}=$ carcinoembryonic antigen; $\mathrm{CPK}-\mathrm{BB}=$ creatine phosphokinase- $\mathrm{BB}$; $\mathrm{CT}=$ calcitonin; $\mathrm{ED}=$ extensive disease; $\mathrm{GRP}=$ gastrin releasing peptide; IGF=insulin-like growth factors; IL-2=interleukin-2; LD=limited disease; NNE=nonneuronal enolase; NSCLC: non small cell lung cancer; NSE=neurone-specific enolase; $\mathrm{POMC}=$ proopiomelanocortin; SCLC: small cell lung cancer; SCC: squamous cell carcinoma; SCC-ag=squamous cell carcinoma antigen; sIL-2R=soluble interleukin-2 receptor; $\mathrm{TM}=$ tumour marker; TPA=tissue polypeptide antigen.
The TM should at least: 1) possess constant serum and/or urinary levels (no major fluctuation); and 2) be of easy and cheap determination.

The initial evaluation of a TM concerns its expression in patients with tumour and in normal subjects in order to define sensitivity and specificity. The sensitivity of a test is defined as the proportion of patients with a disease having a positive test; the specificity is the proportion of patients without tumour who have a negative or normal test.

A problem in the diagnosis of cancer is that nonmalignant diseases can be associated with abnormal marker elevations. For example, even when a marker has a positive predictive value of $95 \%, 5 \%$ of patients with abnormal tests will have no cancer.

Many serum TMs have been singly evaluated as a tool for cancer diagnosis, staging and treatment monitoring. In several instances, TMs have also been evaluated as prognostic factors, either alone, or in combination with other histopathological, biochemical and clinical variables. This review presents data concerning the most studied and interesting markers for lung cancer. A list is shown in table 1.

\section{Tumour-associated antigens}

\section{Carcinoembryonic antigen}

Carcinoembryonic antigens (CEAs) represents a heterogeneous group of glycoproteins, with common antigenic determinants [3]. The single polypeptide chain of the protein 
Table 1. - List of reviewed tumour markers in lung cancer

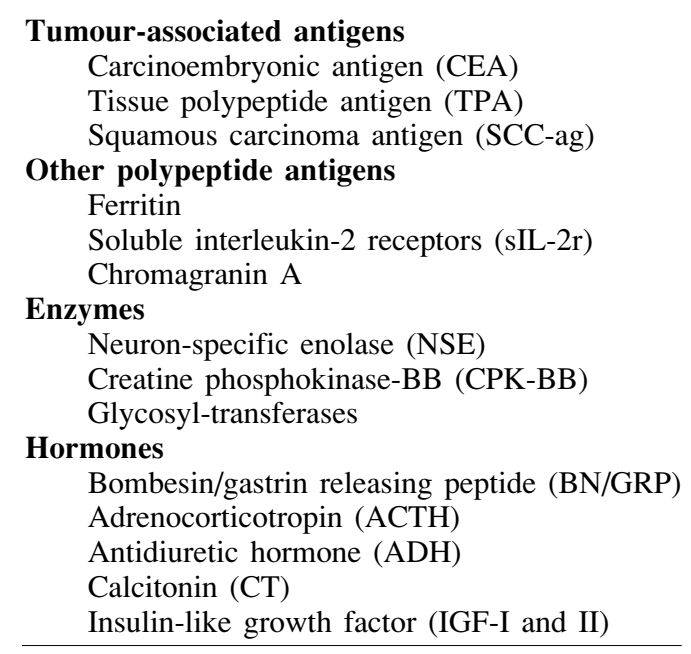

portion appears to account for only about one third of the molecule, the remaining two thirds being carbohydrate [4]. The ratio of protein to carbohydrate may vary from 1:1 to 1:5 in CEAs derived from different tumours [5]. CEA is produced by the secretory cells of the normal adult gastrointestinal tract [6]. An elevation of the concentration of CEA in blood and other body fluids is due to a combination of factors: increase in the number of cells producing CEA, increased synthetic rate in malignant cells, and decreased ability to use normal pathways of excretion from the body. The clearance of CEAs is accomplished primarily in the liver [7], and the highest concentrations of the marker are found in patients with liver metastases from carcinoma of the colon. Nonmalignant diseases of the liver, especially those producing extrahepatic biliary obstruction or intrahepatic cholestasis, will also produce a rise of circulating CEA. The level will decrease when the disease process subsides, or is relieved [8,9].

CEA was first identified by GOLD and FREEDMAN [10], in 1965 as an antigen specific for adenocarcinomas of the digestive tract. Early studies showed that serum concentrations of CEA were higher in healthy cigarette smokers than in nonsmokers $[11,12]$. This was suggested to be the result of epithelial damage in some smokers, with an increased release of the antigen from the lung into the serum [12]. CEA might be an indicator of the small proportion of smokers who are "susceptible" to the effects of cigarette smoke and, thus, to lung diseases [13]. Several nonmalignant disorders may be associated with high values of CEA: alcoholic cirrhosis [14], hepatitis [15], obstructive jaundice [9], ulcerative colitis [16], bronchitis and emphysema [11]. These conditions usually produce transient and only modestly elevated CEA levels, rarely above $10 \mathrm{ng} \cdot \mathrm{ml}^{-1}$, that decrease as the condition improves [17]. The list of malignancies associated with abnormal CEA levels includes: colorectal cancer, pancreatic cancer, breast cancer, prostatic cancer, bladder cancer, gastric cancer, ovarian cancer, neuroblastoma, biliary tract cancer, and osteosarcoma [11, 18-22].

In a large study, partially supported by autopsy material, VINCENT et al. [23] concluded that the level of CEA in lung cancer is not related selectively to the tumour volume, the site of metastasis, or the number of organs involved. This conclusion, however, was at variance with several other studies, which reported increased CEA values in advanced bronchogenic cancers of various histological types [24-29]. A good relationship between CEA levels and treatment response has been demonstrated both in small cell lung cancer (SCLC) and non small cell lung cancer (NSCLC) [23, 24, 27, 29]. Generally, CEA levels vary in accordance with obvious changes in disease status, or may precede their clinical recognition. CEA has been studied as a predictor of survival in both SCLC [23-25, 27, 28, 30-32] and NSCLC [23-25, 27, 32, 33]. Most studies using univariate methods, showed a significant relationship between CEA and prognosis [23-25, 27, 28, 30]. Conflicting results were obtained in studies using multivariate methods $[25,31$, 32, 34].

In conclusion, CEA assays are moderately useful in lung cancer clinical management, as stated at the 1980 consensus conference of the National Institutes of Health at Bethesda [35].

\section{Tissue polypeptide antigen}

Tissue polypeptide antigen (TPA) is a chemically welldefined substance identified by BJÖRKLUND and BJÖRKLUND [36], in 1957. It consists of four protein subunits (A1, B1, B2, C) with molecular weights between 20,000-45,000 Da. The main subunit B1, has been found in foetal tissues at 10,17 , and 24 weeks [37], and with higher concentration in liver, lung, stomach, intestine, kidney and meconium [38]. Increased serum levels of TPA may be present in several nonmalignant diseases: bacterial and viral infections [39], acute hepatitis [40], pregnancy (with particularly high values in the placenta and amniotic fluid [41, 42]), and autoimmune disorders [43]. High levels of TPA have been reported in serum and urine of patients with several tumours, such as carcinoma of the breast, lung, stomach and colonrectum, pancreas, bladder, uterus, prostate, melanoma and lymphoma [44]. TPA is synthesized during the S- to Mphase of the cell cycle and released upon proliferation into the blood stream [45]. Thus, the concentration of the antigen is an indicator of the rate of cell division and tumour aggressiveness, and, therefore, of the host survival.

Mrzushima et al. [46], assaying a panel of diverse tumour markers (carbohydrate antigenic determinant 19-9 (CA-199), CEA, neuron-specific enolase (NSE), squamous cell carcinoma antigen (SCC-ag), and TPA), showed that TPA had a fairly high sensitivity and good diagnostic accuracy (66\% and $82 \%$, respectively). Incidentally, this value was the highest observed by the authors. In lung cancer patients, the pretreatment serum levels of TPA have been shown, by our team, to correlate with both the primary tumour characteristics (defined as T1, T2 and T3), the nodal involvement (N0, N1 and N2), the metastatic status (M0 and M1), and the classification into 4 stages of disease [24, 47-52]. In general, the greater the tumour bulk at diagnosis, the more elevated the serum concentration of the marker [48]. Posttreatment TPA assays may vary in accordance with obvious changes in disease status [24, 47], and may sometimes 
precede them [48] (fig. 1 and table 2). TPA may also be helpful in predicting the course of disease [24, 47, 48, 52, 53]. GRONOwITZ et al. [34] evaluated five tumour markers (i.e. lactate dehydrogenase (LDH), CEA, serum thymidine kinase (S-TK), NSE and TPA) for assessment of prognosis in 125 patients with SCLC. Tissue polypeptide antigen was found to be the most powerful independent prognostic determinant. In a study of 563 untreated patients with lung cancer [54], we confirmed that raised values of this marker are very often associated with shortened survival. In the latter study, a multivariate analysis, including all major prognostic factors, selected TPA as the fourth independent survival predictor. Both univariate and multivariate analyses indicated that the usefulness of this marker is maximum in adenocarcinomas, large cell and small cell carcinomas [54). In a more recent study [32], focusing on 360 patients with squamous cell carcinoma, we further confirmed the prognostic value of TPA.

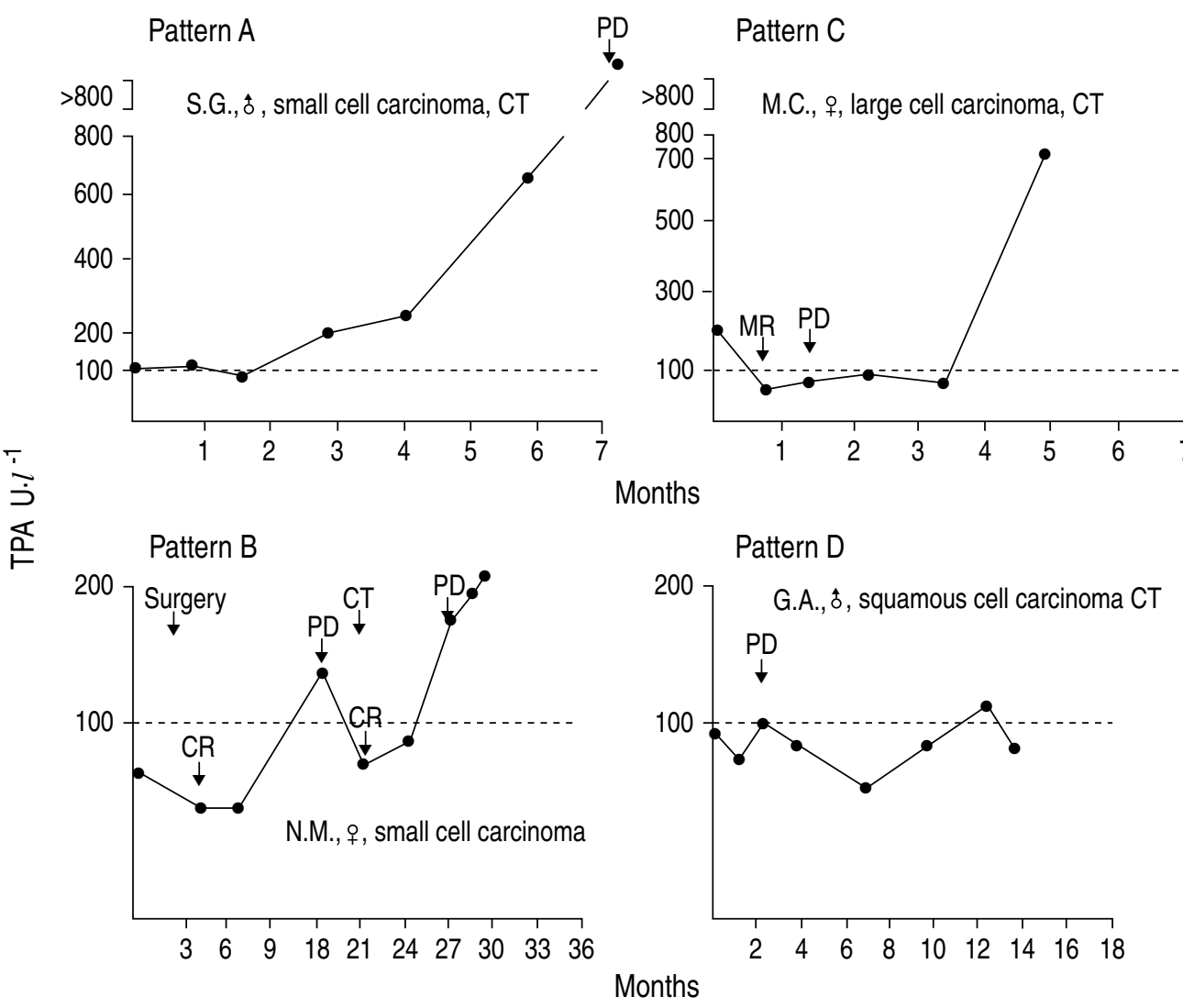

Fig. 1. - Paradigmatic patterns of serial tissue polypetide antigen (TPA) measurements in four patients. Concordant changes of TPA values may precede (Pattern A), be concurrent with (Pattern B) or follow (Pattern C) the clinical recognition of disease status change (PD). In the last example (Pattern D), there is no rise of TPA after disease progression. CT: chemotherapy; RT: radiation therapy ; CR: complete response; MR: minor regression; PD: progressive disease. (From [48]).

Table 2. - Relationships between changes in disease status and TPA serum levels

\begin{tabular}{|c|c|c|c|c|c|c|c|}
\hline \multirow{3}{*}{ Histology } & \multicolumn{7}{|c|}{ Pattern } \\
\hline & \multicolumn{2}{|c|}{ A } & \multicolumn{2}{|c|}{$\mathrm{B}$} & \multicolumn{2}{|c|}{$\mathrm{C}$} & $\mathrm{D}$ \\
\hline & $\mathrm{n}$ & $\%$ & $\mathrm{n}$ & $\%$ & $\mathrm{n}$ & $\%$ & $\mathrm{n} \%$ \\
\hline Squamous cell carcinoma & 17 & 21 & 26 & 33 & 5 & 6 & 3240 \\
\hline Adenocarcinoma & 3 & 27 & 3 & 27 & 1 & 9 & 436 \\
\hline Small cell carcinoma & 8 & 28 & 14 & 48 & 5 & 17 & 27 \\
\hline Large cell carcinoma & 1 & 7 & 8 & 53 & 1 & 7 & 533 \\
\hline Total & 29 & 21 & 51 & 38 & 12 & 9 & 4332 \\
\hline
\end{tabular}

Changes in tissue polypeptide antigen (TPA) concentrations were considered only if at least three consecutive assays showed the same trend or if, in the case of less numerous tests, there was at least a single change from the baseline level of $\geq 35 \%$. As in figure 1 , consistent modifications in TPA profiles were grouped on the basis of whether they preceded (Pattern A), were concurrent to (Pattern B), or followed (Pattern $\mathrm{C}$ ) the clinical recognition of concordant disease status changes, or were totally absent (Pattern D). (From [48]).

\section{Squamous cell carcinoma-related antigen}

Squamous cell carcinoma-related antigen (SCC-ag), a purified subfraction of the tumour antigen 4 , with a molecular weight of $45,000 \mathrm{Da}$, is a new tumour marker that appears to be very promising in the evaluation of cancers of the uterine cervix [55-57]. Elevated serum SCC-ag levels were also found in patients with squamous cell carcinoma (SCC) of the bronchus and nasopharynx, and occasionally in healthy volunteers and patients with tumours of other histological origin [58].

In 1988, MiNo et al. [59] found high serum levels of SCC-ag in $59 \%$ of 76 patients with SCC of the lung, and in only $20 \%$ of patients with other cell types. The mean levels of the marker was 3.6 times higher in patients with SCC of the lung, than in healthy subjects and patients suffering from other types of lung cancer or benign pulmonary diseases. Preliminary data suggest that serum SCC-ag may be useful in evaluating therapeutic effectiveness in SCC. In 
a recent study on 291 patients (129 with SCLC and 162 with NSCLC, including 36 with SCC), BoDy et al. [60] measured both CEA and SCC-ag, and reached the following conclusions: 1) the use of SCC-ag is inappropriate for lung cancer screening in asymptomatic patients; 2) high values can be observed in patients with benign pulmonary disease; 3) SCC-ag serum levels, in contrast to CEA, are not determined by smoking habits; 4) SCC-ag has lower sensitivity but higher specificity than CEA in SCC; and 5) high pretreatment levels are indicative of a negative prognosis. Another study by Mizushima et al. [46] confirmed these results.

\section{Other polypeptide antigens}

\section{Ferritin}

Ferritin is an iron-storage protein with a molecular weight of approximately 450,000 Da. Trace amounts of ferritin are normally present in the serum and other body fluids [61, 62]. Ferritin is present in high concentration in the cytoplasm of reticuloendothelial cells, liver cells, spleen cells, and developing precursors of red cells in bone marrow. Extracts from various tissues have different isoferritin distribution [62-64]. Increased ferritin concentration in the serum or in the cerebrospinal fluid has been found in several malignancies, such as lymphoma [65, 66], acute leukaemia [67], multiple myeloma [68], breast cancer [69], and testicular cancer [70]. Several mechanisms are responsible for the increased concentration of ferritin in malignant disease. They include augmented synthesis in tumour-associated inflammations [71], increased secretion by malignant cells [72], and hepatocellular necrosis caused by liver metastases.

Conflicting results have been obtained concerning the possible clinical utility of this substance in lung cancer. GropP et al. [73], demonstrated that ferritin levels were significantly higher in metastatic disease, irrespective of the histological type. In their study, serial measurements of ferritin were useful in evaluating the effects of therapy. Another study, by Cox et al. [74], showed that ferritin was considerably higher in 39 SCLC patients than in normal individuals, but no relationship was found with the disease extent and the clinical course. In the same study, patients with low pretreatment levels of ferritin had a significantly longer median survival time. From 1988 until 1990, we performed 169 pretreatment and 31 post-treatment assays of serum ferritin in lung cancer patients $[75,76]$. The combined prognostic significance of 31 other clinical or biological pretreatment characteristics, including the serum concentrations of CEA and TPA, was studied. We were, however, unable to show any significant relationship between serum levels of ferritin and histological type, clinical stage of disease, or response to treatment. Patients with ferritin levels below the median $\left(236 \mathrm{ng} \cdot \mathrm{ml}^{-1}\right)$ had a more favourable outcome, in accordance with the findings by Cox et al. [74]. In addition, ferritin was selected as an independent variable in a multivariate survival model, including the most important prognostic factors, other than tumour burdenrelated variables $[75,76]$.
In conclusion, ferritin may have some prognostic significance in lung cancer, but does not appear to be useful for staging and monitoring.

\section{Soluble interleukin-2 receptor}

Interleukin-2 (IL-2) is a well-characterized cytokine, with various immunological functions, the most important one being the capacity to initiate the proliferation of activated $\mathrm{T}$ cells [77]. This property has stimulated the recent renewal of interest in immunotherapy of cancer [78]. IL-2 acts upon a specific surface receptor [IL-2R], absent in resting T cells but appearing within hours of activation [79]. Activated lymphocytes produce and release into the circulation a soluble form of the same receptor (sIL-2R), that retains the capability of binding the lymphokine [80]. Serum levels of SIL-2R may be elevated in patients with virus infections [81, 82], sarcoidosis [83], Grave's disease [84], organ transplants [85, 86], lymphoproliferative disorders [87, 88], and solid tumours [89, 90].

MARINO et al. [91] reported increased levels of sIL-2R in serum samples of patients with untreated lung cancer. In various human malignancies, a relationship has been observed between sIL-2R and some clinical parameters, such as tumour burden and treatment response [89, 90]. Recently, our group performed 326 sIL-2R serum assays in 126 lung cancer patients, 112 patients with pulmonary benign disease, and 63 healthy volunteers [92]. We found increased concentrations of sIL-2R in lung cancer, compared to controls and noninflammatory pulmonary benign disease. Pretreatment sIL-2R correlated neither with the stage of disease nor with the cell type [92]. On the contrary, post-treatment levels of the receptor correlated significantly with the status of disease, particularly in nonsurgical patients. Raised pretreatment values of sIL-2R were associated with a shortened survival [92]. GINNs et al. [93] confirmed that patients with lung cancer (squamous cell carcinoma (SCC) or adenocarcinoma (AC)) have high values of sIL-2R. In patients with AC of the lung, the level of sIL-2R did not correlate with the extent of the disease, as in our study. In SCC patients, however, the peripheral blood concentration of sIL-2R appeared to be inversely correlated with the bulk of disease. In fact, the highest levels were found in patients with asymptomatic stage I disease.

Soluble interleukin-2 receptor may be an important marker of the immune alterations associated with lung cancer. Activation of the immune response, reflected by an elevated concentration of sIL-2R, may either enhance host defences or promote tumour development through various growth factors.

\section{Chromogranin A}

Chromogranin $\mathrm{A}$ is a $68,000 \mathrm{Da}$ protein, that has been demonstrated in serum of patients with lung cancer and, by immunohistochemical techniques, in sections from lung tumours [94, 95]. O'CONNOR and DeFTOS [96] observed chromogranin $\mathrm{A}$ in a wide variety of neuroendocrine tumours. NAKAJAMA et al. [94] found a positive reaction to 
chromogranin A in 5 out of 29 biopsy specimens from SCLC examined [94], whilst SAID et al. [95] failed to demonstrate any positive histochemical reaction in 12 cases of SCLC [35]. Sobol et al. [97] assayed the sera of 46 patients with SCLC: $52 \%$ of those patients with limited disease (LD) and $72 \%$ of those with extensive disease (ED) had elevated levels of chromogranin A. In the same study, four patients with elevated chromogranin A levels, originally classified as NSCLC, were eventually found to have a mixed SCLC and NSCLC histology [97].

\section{Enzymes}

\section{Neuron-specific enolase}

Enolase molecules in mammalian tissues are dimers composed of three immunologically distinct subunits [98, 99]. The $\alpha$ subunit of enolase ( $\alpha$-enolase) is widely distributed in various tissues. The $\beta$ subunit ( $\beta$-enolase) is found mainly in the heart and other striated muscles. The $\gamma$ subunit $(\gamma$ enolase), which has been designated as neuron-specific enolase (NSE), is highly concentrated in neurons, neuroendocrine cells [100], and in neurogenic tumours [101, 102]. Significant levels of $\gamma$-enolase have also been found in smooth muscle tissues [103, 104], blood platelets and lymphocytes [105]. Recently, НАIмото et al. [106] have found $\gamma$-enolase in other nonneuron cells and in nonneuroendocrine tissues, such as epithelial cells of the loops of Henle, macula densa cells of the kidney, the conducting system of the heart, bronchial epithelial cells, and type II pneumocytes.

Several studies have determined serum NSE levels in patients with bronchogenic carcinoma. Elevated serum concentrations of NSE have been found in approximately $70 \%$ of 450 cumulated patients with SCLC [107-112], and in only $14 \%$ of 190 NSCLC patients [108, 110, 112]. High pretreatment values of NSE were noted in $38-71 \%$ of SCLC patients with LD, and in 83-98\% of those with ED (table 3) [107-112]. Like few other markers, NSE levels may fall with the clinical response to chemotherapy, and rise again during tumour progression or relapse. Sequential measurements of this marker may anticipate the clinical detection of relapse [109, 111]. Daily serum determinations of NSE, performed immediately before and after cytotoxic therapy, may also be predictive of the overall response. Usually, transient elevations of NSE are seen immediately

Table 3. - Raised levels of NSE in serum of untreated SCLC patients

\begin{tabular}{lcrc}
\hline Study & [Ref. No.] & LD & ED \\
\hline CARNEY et al. & {$[107]$} & $15 / 38$ & $49 / 56$ \\
ARIYOSHI et al. & {$[108]$} & $6 / 13$ & $24 / 27$ \\
COOPER et al. & {$[109]$} & $25 / 38$ & $34 / 39$ \\
ESSCHER et al. & {$[110]$} & $34 / 48$ & $54 / 55$ \\
JoHNSON et al. & {$[111]$} & $23 / 39$ & $45 / 54$ \\
AKOUN et al. & {$[112]$} & $6 / 16$ & $22 / 27$ \\
\hline
\end{tabular}

NSE: neuron-specific enolase; SCLC: small cell lung cancer; LD: limited disease; ED: extensive disease. after chemotherapy, followed by a subsequent decline to lower or normal values [110,112, 113]. Several reports have assessed the prognostic capability of NSE. A significant inverse correlation between NSE levels and survival has been found at univariate analysis [30, 34, 114-116]. However, less unequivocal results were reported by JORGENSEN et al. [114] and GRONOwITZ et al. [34], using multivariate analyses.

Recently, ViallaRd et al. [117] suggested that the NSE/nonneuronal enolase (NNE) ratio increases the ability of the test to separate SCLC from NSCLC patients. In fact, the NSE/NNE ratio misclassified only three out of 57 NSCLC $(5.3 \%$ of false positive). Its sensitivity was 76 and $100 \%$ in the diagnosis of SCLC (for LD and ED, respectively). This index could represent a better approach for diagnosis, assessment of therapeutic effect, and detection of SCLC relapse.

\section{Creatine phosphokinase- $B B$}

In 1981, GAZDAR et al. [118] found abnormal concentrations of the isoenzyme $\mathrm{BB}$ of creatine phosphokinase (CPK$\mathrm{BB}$ ) in most extracts and in the supernatants of SCLC growing in tissue culture. Creatine phosphokinase is an enzyme which reversibly catalyses the transfer of a high energy phosphate from creatine phosphate to adenosine diphosphate (ADP). CPK levels are 10-100 times higher in clinical specimens and in established cell lines of SCLC than in normal lung tissue, in NSCLC, and in normal cell cultures [119]. Interestingly, "variant" SCLC cell lines that lose L-Dopa decarboxylase activity retain high levels of CPK-BB [120]. In two recent clinical studies, CPK-BB was elevated in about $41 \%$ of untreated patients with extensive SCLC, but in only $2 \%$ of patients with LD [118, 121]. A direct correlation between the number of metastatic sites and the serum level of the isoenzyme, as well as an inverse correlation with survival were also described $[118,121]$. BORK et al. [122] reported the most frequent elevations of serum CPK-BB, 82 and $50 \%$ in untreated SCLC patients with $\mathrm{ED}$ and $\mathrm{LD}$, respectively. High concentrations of the isoenzyme in cerebrospinal fluid were useful to distinguish between meningeal spread and parenchymal cerebral metastases [123].

\section{Glycosyltransferases}

The glycosyltransferases constitute a group of enzymes which catalyses the transfer of individual sugars from nucleotide-sugar precursor molecules into appropriate acceptors [124]. An increase in serum glycosyltransferase activity has been observed in various malignancies [125-128]. The a-(1-3)-L-fucosyltransferase is one of the glycosyltransferases thought to be responsible for the synthesis of tumour-associated antigens [128-130]. The accumulation of tumour-associated antigens, such as carcinoembryonic antigen and sialyl Lewis $\chi-\mathrm{i}$, has frequently been observed in the sera of patients with lung cancer [131-133]. Recently, AsAO et al. [134] performed a clinical evaluation of a-(1-3)L-fucosyltransferase. They observed higher serum levels of 
the enzyme in patients with lung cancer, compared to patients with benign pulmonary diseases and healthy controls. The elevation of enzyme activity correlated significantly with the clinical stage and with the size of the primary tumour, whereas there were no differences in enzyme activity among the histological types [134]. Follow-up studies showed that, in some patients, glycosyltransferase measurements were helpful in monitoring the clinical course of disease [134]. The utility of the enzyme as a diagnostic marker was obvious when its levels were compared with those of CEA and sialyl Lewis $\chi$-i antigen [134].

\section{Hormones}

\section{Bombesin/gastrin releasing peptide}

Bombesin $(\mathrm{BN})$ is an amphibian skin peptide of 14 amino acids [135]. Gastrin releasing peptide (GRP), the mammalian equivalent of $\mathrm{BN}$, consists of 27 amino acids, and is able to release gastrointestinal hormones [136]. Cells containing GRP are rare in the normal adult lung, but are regularly found in the foetal and infantile epithelium of the lung [137]. A bombesin-like immunoreactivity has been demonstrated in normal human brain tissue, peripheral nerves, and neuroendocrine bronchial cells [136, 138, 139]. Notably, SCLC is often equipped with receptors for GRP [140], which has a growth promoting activity in SCLC [141]. Unfortunately, increased concentrations of GRP in the serum are rare, because of the very short half-life [142-144]. For the same reason, high concentrations of the hormone may be found in neoplastic tissues, without corresponding serum increase [139]. Recently, a radioimmunoassay for a GRP precursor has been developed; using this assay, elevated plasma concentrations of pro-GRP have been found in $72 \%$ of 71 SCLC patients [145]. In a study by PEDERSEN $e t$ al. [146], high plasma levels of BN/GRP were demonstrated in the fluid of patients with meningeal carcinomatosis from SCLC, independent of a positive cytology. Combining calcitonin (CT) and BN findings increased the overall detection rate of patients with central nervous system (CNS) metastases to $67 \%$. Importantly, $93 \%$ of patients with increased BN or calcitonin had CNS metastases. However, with regard to meningeal carcinomatosis, $\mathrm{BN}$ alone was just as sensitive and specific as the combined CT and BN analysis [146].

\section{Adrenocorticotropic hormone and related molecules}

Ectopic secretion of adrenocorticotropic hormone (ACTH) was initially observed in 1928 by BROwN [147] in a patient with Cushing's syndrome and small cell carcinoma of the lung (SCLC). Ectopic ACTH production has been described in association with many malignancies, i.e. ovarian tumours, thymoma, islet cell cancer of the pancreas, medullary cancer of the thyroid, and carcinoid tumour [148, 149].

Elevated serum levels of ACTH have been reported in $25-30 \%$ of patients with SCLC [150-152]. The clinical picture of ectopic Cushing's syndrome is characterized by oedema, hypokalaemia or impaired glucose tolerance without obesity, striae and osteoporosis. Its frequency ranged $1-5 \%$ of 346 SCLC patients in five consecutive series [153-157]. Conflicting results have been reported concerning a possible correlation between serum levels of the hormone and stage of disease, treatment response, and survival of patients with lung cancer [150, 151, 155, 158].

The common precursor to ACTH is pro-opiomelanocortin (POMC), which has been shown to be abnormally elevated in the plasma of lung cancer patients with epidermoid, adeno- and small cell type [159]. A significant difference between pulmonary vein and artery concentrations provides evidence that POMC is synthesized by the bronchogenic tumour [159]. The $\mathrm{NH}_{2}$ terminal portion of this molecule is easier to assay than ACTH, and may be the more appropriate antigen to use as tumour marker.

Summing up, ACTH seems to be neither a specific nor a sensitive indicator of lung malignancy, nor does it appear to be reliable in monitoring the response to therapy, or in predicting relapses.

\section{Antidiuretic hormone}

Hyponatraemia was first observed in association with cancer in 1938 [160]. In 1957, SCHWARTZ et al. [161] postulated inappropriate secretion of vasopressin, also known as antidiuretic hormone (ADH), as the cause of persistent hyponatraemia in two patients with bronchogenic carcinoma. Subsequently, GeORGE et al. [162] demonstrated in vitro biosynthesis of $\mathrm{ADH}$ in short-term culture of lung cancer. Other malignancies with ectopic secretion of ADH include: bronchial carcinoid tumours, adenocarcinoma of the pancreas, Hodgkin's disease, bladder carcinoma, thymoma, mesothelioma, leiomyosarcoma of the stomach, prostatic carcinoma, and adrenocortical cancer [163].

Inappropriate $\mathrm{ADH}$ secretion has been demonstrated in SCLC patients, with rates depending on the method used for the hormone identification [164]. The concentration of $\mathrm{ADH}$ was elevated in $35 \%$ of 279 patients with SCLC $[151,165-168]$, whilst the frequency of the clinical syndrome was quite low (approximately 10\% of 596 patients in six different studies [153-157, 169]). Elevated serum levels of $\mathrm{ADH}$ did not correlate with the stage of disease [151], or with the response to treatment [158]. Tumour-produced $\mathrm{ADH}$ may be bound to neurophysin, as in the posterior pituitary. MAURER et al. [170] found that plasma concentrations of ADH-neurophysin were elevated in $65 \%$ of 103 patients with SCLC. In patients with initially high values, concentrations were related to the response to therapy, whilst initially normal levels were of no use in disclosing subsequent relapses [168].

\section{Calcitonin}

Calcitonin (CT) is a 32 amino acid peptide, with a molecular weight of 3,419 Da synthesized by the thyroid C cells [171]. Normally, CT is secreted by the thyroid in response to increased plasma calcium concentration, or following the stimulation of certain gastrointestinal hormones. The 
hormone inhibits the release of calcium and phosphate from bone [172].

Marked elevations of serum calcitonin are usually found in familial medullary thyroid carcinoma [173]. Elevated levels have also been reported in other malignancies, including breast cancer, carcinoid tumour, hepatoma, renal cell carcinoma, and gastrointestinal cancer [174].

Calcitonin was elevated in $59 \%$ of 425 SCLC patients [151, 175-180]. Elevated concentrations are rare in other types of lung cancer $[177,181]$. Serum concentrations of CT do not seem to be correlated with stage of disease. However, merging the data from three studies, an increase of calcitonin has been found in $80 \%$ of 81 patients with ED, and in only $56 \%$ of 71 patients with LD [151, 175, 181]. Conflicting reports about the use of calcitonin in monitoring treatment response have so far been published. WALLACH $e t$ al. [180] reported a decrease of CT serum levels in SCLC patients responding to chemotherapy, and an increase in progressive diseases. Mulder et al. [182], on the contrary, showed no such effect.

In conclusion, the assay of serum calcitonin seems to be a general indicator of the course of SCLC disease, but it is not sufficiently reliable for evaluating the response to treatment.

\section{Insulin-like growth factors}

The insulin-like growth factors [IGF], or somatomedin, are polypeptides of about $7.5 \mathrm{kDa}$, having a structural similarity to pro-insulin [183]. Insulin-like growth factors I and II (IGF-I, IGF-II) share a 62\% sequence homology. Their action is mediated through 2 distinct receptors with different characteristics [184, 185]. IGF-I is mitogenic for both classic and variant SCLC cell lines [186], and this suggests that IGF-I may be an autocrine growth factor for human SCLC.

There are contrasting reports concerning the utility of IGF as a tumour marker. MACAULY et al. [187] measured serum IGF-I concentrations in 42 SCLC patients, and concluded that IGF-I levels do not correlate with the tumour bulk, or with the therapeutic responsiveness of SCLC. REEVE et al. [188] found elevated levels of these proteins in the serum of patients with both SCLC and NSCLC, and a good correlation between circulating levels and clinical course. Further studies are needed for a better evaluation of these substances.

\section{Conclusion}

Lung cancer is the most common and lethal malignant neoplasm in the Western world, and is also becoming one of the major health problems in undeveloped countries [189]. Its devastating incidence and clinical seriousness have stimulated innumerable research studies, with any possible approach.

Historically, NSCLC and SCLC were considered to have different origins (ectodermal and endodermal, respectively), thus, accounting for the many differences observed in their clinical behaviour. However, in more recent years, it has become clear that considerable overlaps exist between SCLC and NSCLC. Several data suggest a common stem for all lung cancers, supporting the concept that individual tumours may spontaneously differentiate into other cell types. Histological evaluation of specimens of untreated lung cancers reveals that about $15 \%$ of SCLC tumours contains NSCLC subtypes. In 13-28\% of autopsy specimens from patients treated with cytotoxic therapy for SCLC, a mixed histology was proved [190-194]. TERASAKI et al. [195] reported that changes of the culture medium may, in some cases, induce chances in SCLC morphology from small cell to squamous cell and vice versa. The expression of neuroendocrine biomarkers is detected in $15 \%$ of NSCLC cell lines [196, 197].

The above data on the clonal heterogeneity of lung cancer may explain the several limitations in the clinical use of serum tumour markers. Indeed, none of the serum components proposed, so far, seems to be sufficiently sensitive and specific to be reliable in the screening and diagnosis of lung cancer. The most fruitful application at present is monitoring of tumour activity. During active therapy, a marker can give an accurate estimate of the effectiveness of treatment. Earlier detection of relapse may allow a modification of therapy at a time that might precede the normal clinical evidence of tumour recurrence by several weeks. TPA, CEA, and SCC-ag seem to be the most fruitful in NSCLC; NSE, BN/GRP and CPK-BB in SCLC patients. Other TMs are worthy of further investigations, whilst peptide hormones have been almost definitively omitted.

The study of these substances may lead to a better understanding of the biological characteristics of bronchogenic carcinoma as occurred recently, when SCLC was reclassified according to its biological characteristics [198], and ultimately to new therapeutic strategies for each tumour histotype.

Acknowledgements: The authors thank A. Cerchietti for her linguistic aid, and A. Merlo for her excellent secretarial assistance.

\section{References}

1. Coombes RC, Neville AM. - Significance of tumor-index substances in management. In: Stoll BA, ed. Secondary Spread in Breast Cancer. Chicago, William Heinemann Medical Books, Chicago 1978.

2. Coombes RC, Powels TJ. - Tumour markers in the management of human cancer. In: Deeley TJ, ed. Topical Reviews in Radiotherapy and Oncology. Bristol, Wright PGS., 1982; p.39.

3. Coligan JE, Henkart PA, Todd CW, Terry W. - Heterogeneity of the carcinoembryonic antigen. Immunochemistry 1973; 10: 591-599.

4. Pritchard DG, Todd CW. - The chemistry of carcinoembryonic antigen. In: Herberman RB McIntire J, eds: Immuno- diagnosis of Cancer. New York, Marcel Dekker, 1979.

5. Banjo C, Shuster J, Gold P. - Intermolecular heterogeneity of the carcinoembryonic antigen. Cancer Res 1974; 34: 2114-2121.

6. Go VLW, Ammon HW, Holtermuller KH, et al. - Quantification of carcinoembryonic antigen-like activities in normal human gastrointestinal secretions. Cancer 1975; 36: 2346-2350.

7. Thomas P, Zamcheck N. - Role of the liver in clearance 
and excretion of circulating carcinoembryonic antigen (CEA). Dig Dis Sci 1983, 28: 216-224.

8. Moore TL, Ohar P, Zamcheck N, et al. - Carcino-embryonic antigen(s) in liver disease: I. Clinical and morphological studies. Gatroenterology 1972; 63: 88-94.

9. Lurie BB, Loewenstein MS, Zamcheck N. - Elevated carcinoembryonic antigen levels and biliary tract obstruction. J Am Med Assoc 1975; 233: 326-330.

10. Gold P, Freedman SO. - Demonstration of tumorspecific antigens in human colonic carcinomata by immunological tolerance and absorption techniques. J Exp Med 1965; 121: 439-462.

11. Hansen HJ, Snyder LJ, Miller E, et al. - Carcinoembryonic antigen (CEA) assay. A laboratory adjunct in the diagnosis and management of cancer. J Hum Pathol 1974; 5: 139-147.

12. Clarke C, Hine HR, Dykes PW, Whitehead TP, Whitfield AGW. - Carcinoembryonic antigen and smoking. $J$ Roy Coll Phys (Lond), 1980; 14: 227-228.

13. Merril WW, Goodman M, Matthay RA, Naegel GP, et al. - Quantitation of carcinoembryonic antigen in lung lining fluids of normal smokers and nonsmokers. Am Rev Respir Dis 1981; 123: 29-31.

14. Khoo SK, Warner NL, Lie JT, et al. - Carcinoembry-onic antigen activity of tissue extracts: a quantitative study of malignant and benign neoplasms, cirrhotic liver, normal adult and fetal organs. Int J Cancer 1973; 11: 681-687.

15. Khoo SK, MacKay IR. - Carcinoembryonic antigen in serum in diseases of the liver and pancreas. J Clin Pathol 1973; 26: 470-475.

16. Gardner RC, Feinerman AE, Kantrowitz PA, et al. Serial carcinoembryonic antigen (CEA) blood levels in patients with ulcerative colitis. Am J Dig Dis 1978; 23: 129-134.

17. Loewenstein MS, Zamcheck N. - Carcinoembryonic antigen and the liver. Gastroenterology 1977; 72: 161-166.

18. Stewart AM, Nixon D, Zamcheck N, et al. - Carcinoembryonic antigen in breast cancer patients: serum levels and disease progress. Cancer 1974; 33: 1246-1254.

19. Seppala M, Pihko H, Ruoslahti E. - Carcinoembryonic antigen and alpha-fetoprotein in malignant tumors of the female genital tract. Cancer 1975; 35: 1377-1381.

20. Orjasaeter H, Fossa SD, Schjolseth SA, et al. - Carcinoembryonic antigen (CEA) in plasma of patients with carcinoma of the bladder/urethra. Cancer 1978; 42: 287-295.

21. Rimsten A, Adami HO, Wahren B. - Carcinoembryonic antigen in serum of unselected breast cancer patients and of non-hospitalized controls. Br J Cancer 1979; 3: 109-115.

22. Moore TH, Kupchik HZ, Marcon N, et al. - Carcinoembryonic antigen in carcinoma of the colon and pancreas and other digestive tract disorders. Am J Dig Dis 1971; 16: $1-7$.

23. Vincent RG, Chu TM, Fargen TB, Ostrander M. Carcino-embryonic antigen in 228 patients with carcinoma of the lung. Cancer 1975; 36: 2069-2076.

24. Buccheri GF, Violante B, Sartoris AM, Ferrigno D, et al. Clinical value of a multiple biomarker assay in patients with bronchogenic carcinoma. Cancer 1986; 57: 2389-2396.

25. Muller T, Marshall RJ, Cooper EH, et al. - The role of serum tumour markers to aid the selection of lung cancer patients for surgery and the assessment of prognosis. Eur $J$ Cancer Clin Oncol 1985; 12: 1461-1466.

26. Rasmuson T, Bjork GR, Dambe L, et al. - Tumor markers in bronchogenic carcinoma. Acta Radiol Oncol 1983; 22: 209-214.

27. Concannon JP, Dalbow MH, Hodgson SE, et al. Prognostic value of preoperative carcinoembryonic antigen
(CEA) plasma levels in patients with bronchogenic carcinoma. Cancer 1978; 42: 1477- 1483.

28. Sculier JP, Feld R, Evans WK, et al. - Carcinoembryonic antigen: a useful prognostic marker in small cell lung cancer. J Clin Oncol 1985; 12: 1461-1466.

29. Goslin RH, Skarin AT, Zamcheck N. - Carcinoembryonic antigen: a useful monitor of therapy of small cell lung cancer. J Am Med Assoc 1981; 24: 2173-2176.

30. Ferrigno D, Buccheri GF, Cecchini C, Marchetti G. Clinical value of a multiple biomarker assay (CEA, TPA, NSE) in patients with small cell lung cancer. GIMT 1990; 44: $135-140$.

31. Laberge F, Fritsche H, Umsawasdi T, Carr DT, et al. Use of carcinoembryonic antigen in small cell lung cancer. Prognostic value and relation to the clinical course. Cancer 1987; 53: 2047-2052.

32. Buccheri GF, Ferrigno D, Vola F. - Carcinoembryonic antigen (CEA), tissue polypeptide antigen (TPA), and other prognostic indicators in squamous cell lung cancer. Lung Cancer (in press).

33. Dent PB, McCulloch PB, Wesley-James O, et al. Measurements of carcinoembryonic antigen in patients with bronchogenic carcinoma. Cancer 1978; 42: 1484-1491.

34. Gronowitz JS, Bergstrom R, Nou E, Pahalmam S, et al. Clinical and serological markers of stage and prognosis in small cell lung cancer. A multivariate analysis. Cancer 1990; 66: 722-732.

35. N.H.I. - Carcinoembryonic antigen: its role as a marker in the management of cancer. Br Med J 1981; 282: 373-375.

36. Björklund B, Björklund V. - Antigenicity of pooled human malignant and normal tissue by cyto-immunological technique: presence of an insoluble heat-labile tumor antigen. Int Arch Allergy 1957; 10: 153-183.

37. Luning B, Redelius P, Wiklund B, Björklund B. Chemical studies of TPA. In: Petrs H, ed. Protides of the Biological Fluids. Oxford, Pergamon Press, 1976; p.513.

38. Björklund B. - Tissue Polypeptide antigen (TPA). In: Hautkamp H, Hogman A, eds. Laboratory Testing in Cancer. Stockholm, Folksam, 1979; p. 5.

39. Lundström R, Björklund B, Eklund G. - A tissue derivedpolypeptide antigen: its relation to cancer and its temporary occurrence in certain infectious diseases. In: Björklund B eds. Immunological techniques for Detection of Cancer. Stockholm, Bonniers, 1973; p. 243.

40. Sylvan S. - TPA in acute hepatitis. In: Hautkamp H, Hogman A, eds. Laboratory Testing in Cancer. Stockholm, Folksam, 1979; p. 35.

41. Björklund B, Björklund V, Wiklund B, et al. - A human tissue polypeptide related to cancer and placenta. I. Preparation and properties. II. Assay technique. III. Clinical studies of 1,483 individuals with cancer and other conditions. In: Björklund $\mathrm{B}$, eds. Immunological technique for Detection of Cancer. Stockholm, Folksam, 1973; p. 133.

42. Oehr P, Bellmann O, Hamann D. - Measurement of tennesse antigen, carcinoembryonic antigen, tissue polypeptide antigen and alpha-protein in body fluids associated with pregnancy. Clin Biochem 1982; 15(1): 13.

43. Ruibal A, Clotet B, Pigrau C, et al. - Tissue Polypeptide antigen in autoimmune diseases. Tumor Diag Therapie 1982; 1: 40 .

44. Menendez-Botet CJ, Oettgen HF, Pinsky CM, Schwartz MK. - A preliminary evaluation of tissue polypeptide antigen in serum or urine (or both) of patients with cancer or benign neoplasm. Clin Chem 1978; 24: 868-872.

45. Björklund B, Björklund V. - Specificity and basis of the tissue polypeptide antigen. Cancer Detect Prev 1983; 6: $41-50$. 
46. Mizushima Y, Hirata H, Izumi S, et al. - Clinical significance of the number of positive tumor markers in assisting the diagnosis of lung cancer with multiple tumor marker assay. Oncology 1990; 47: 43-48.

47. Buccheri GF, Ferrigno D, Sartoris AM, et al. - Tumor markers in bronchogenic carcinoma. Superiority of tissue polypeptide antigen to carcinoembryonic antigen and carbohydrate antigenic determinant 19-9. Cancer 1987; 60: 42-50.

48. Buccheri GF, Ferrigno O. - Usefulness of tissue polypeptide antigen in staging, monitoring, and prognosis of lung cancer. Chest 1988; 93: 565-570.

49. De Angelis G, Cipri A, Fiori F, Munno R, Pau F, Pigorini F. - Valutazione dei titoli plasmatici dell'antigene carcinoembrionario (CEA) e dell'antigene pilipeptidico tissutale (TPA) in 158 sogsetti normali e in 140 pazienti con carcinoma polmonare primitivo. Min Pneumol 1985; 24: 1-33.

50. Luthgens M, Schlegel G. - Verlaufskontrolle bei bronchialkarzinomen mit tissue polypeptide antigen und carcinoembryonalem antigen. Tumor Diag Ther 1985; 6: 1-7.

51. Schultek T, Wood WG. - Tissue polypeptide antigen (TPA) as prognostic parameter in small-cell and non-smallcell bronchial carcinoma. Arztl Lab 1985; 31: 273-279.

52. Pau F, De Angelis G, Antilli A, et al. - Valore prognostico dell'antigene carcinoembrionario (CEA) e dell'antigene polipeptidico tissutale (TPA) nel cancro Polmonare primitivo "non small cell". Min Pneumol 1985; 24: 27-29.

53. Volpino P, Cangemi V, Caputo V, et al. - Clinical usefulness of serum TPA (tissue polypeptide antigen) in postsurgical diagnosis, prognosis and follow-up of lung cancer. J Nucl Med Allied Sci 1985; 29: 241-244.

54. Buccheri GF, Ferrigno D. - Prognostic value of the tissue polypeptide antigen (TPA) in lung cancer. Chest 1992; 5: 1287-1292.

55. Kato H, Tamai K, Morioka H, et al. - Tumor-antigen TA4 in the detection of recurrence in cervical squamous cell carcinoma. Cancer 1984; 54: 1544-1546.

56. Senekjian EK, Young JM, Weiser PA, et al. - An evaluation of squamous cell carcinoma antigen in patients with cervical squamous cell carcinoma. Am J Obstet Gynecol 1987; 157: 433-439.

57. Crombach G, Wurz H, Kreienberg R, et al. - Evaluation of SCC antigen as a tumor marker for cervical cancer: a cooperative study of the GTMG. I Tumor Marker Oncol 1988; 3: 59-63.

58. Kato H, Miyauchi M, Morioka M, et al. - Tumor antigen of human cervical squamous carcinoma. Correlation of circulating levels with disease progress. Cancer 1979; 43: 585-590.

59. Mino M, Ho A, Hamamoto K. - Availability of Tumorantigen 4 as a marker of squamous cell carcinoma of the lung and other organs. Cancer 1988; 62: 730-734.

60. Body JJ, Sculier JP, Raymakers N, et al. - Evaluation of squamous cell carcinoma antigen as a new marker for lung cancer. Cancer 1990; 65: 1552-1556.

61. Clichton RR. - Ferritin: structure, synthesis and function. N Engl J Med 1971; 284: 1413-1422.

62. Aungst CW. - Ferritin in body fluids. J Lab Clin Med 1968; 71: 517-522.

63. Drysdale JW, Kohgo Y, Watanabe N. - Radioimmunoassay of hormones, proteins, and enzymes: In: A. Albertini ed. Ferritin Phenotypes. Amsterdam, Excerpta Medica 1980; p. 213.

64. Halliday JW, Powell LW. - Serum ferritin and isoferritin in clinical medicine. Prog Haematol 1979; 11: 229.

65. Jacobs A, Slater A, Whittaker JA, et al. - Serum ferritin concentrations in untreated Hodgkin's disease. Br J Cancer 1976; 34: 162-166.
66. Matzner Y, Konijn AM, Hershko C. - Serum ferritin in hematologic malignancies. Am J Hematol 1980; 9: 13-22.

67. Parry DH, Worwood M, Jacobs A. - Serum ferritin in acute leukaemia at presentation and during remission. $\mathrm{Br}$ Med Bull 1975; 1: 245-249.

68. Patel R, Shan PC, Vohra RM, et al. - Serum ferritin levels in hematological malignant neoplasm. Arch Pathol Lab Med 1980; 104: 509-514.

69. Jacobs A, Jones B, Ricketts C, Bulbrook RD, Wang DY. Serum ferritin concentrations in early breast cancer. $\mathrm{Br} J$ Cancer 1976; 34: 286-289.

70. Wahren B, Alpert E, Esposti B. - Multiple antigens as marker substances in germinal tumors of the testis. JNCI 1977; 58: 489-493.

71. Hershko C, Konjin AM. - Pathogenesis of impaired iron release in inflammation. In: Brow E, ed. Proteins of Iron Metabolism. Philadelphia, Grune \& Stratton, 1977; pp. 417-425.

72. White GP, Worwood M, Parry D. - Ferritin synthesis in normal and leukemic leucocytes. Nature 1974; 250: 584-586.

73. Gropp C, Havemann K, Lehmann FG. - Carcinoembryonic antigen and ferritin in patients with lung cancer before and during therapy. Cancer 1978; 42: 2802-2808.

74. Cox R, Gyde OH, Leyland MJ. - Serum ferritin levels in small cell lung cancer. Eur J Cancer Clin Oncol 1986; 22: 831-835.

75. Ferrigno D, Buccheri GF. - Serum ferritin levels in lung cancer patients. Eur J Cancer 1992; 28: 241.

76. Ferrigno D, Buccheri GF. - Comprehensive evaluation of serum ferritin levels in lung cancer patients. Lung Cancer 1992; 8: 85-94.

77. Dinarello CA, Mier JW. - Lymphokines. N Engl J Med 1987; 317: 940-945.

78. Oliver RTD. - The clinical potential of interleukin-2. $\mathrm{Br} J$ Cancer 1988; 58: 405-409.

79. Waldmann TA. - The structure, function, and expression of interleukin-2 receptor. Science 1986; 232: 727-732.

80. Rubin LA, Jay G, Nelson DL. - The released interleukin2 receptor binds interleukin-2 efficiently. J Immunol 1986; 137: 3841-3844.

81. Muller C, Knoflach P, Zielinski C. - Soluble interleukin2 in acute viral hepatitis and chronic liver disease. Hepatology 1989; 10: 928-932.

82. Kloster BE, John PA, Miller LE, et al. - Soluble interleukin-2 receptors are elevated in patients with AIDS or at risk of developing AIDS. Clin Immunol Immunopathol 1987; 45: 440-446.

83. Semenzato G, Cipriani A, Trentin L, et al. - High serum levels of soluble interleukin-2 receptors in sarcoidosis. Sarcoidosis 1987; 4: 25-27.

84. Nakanishi K, Taniguchi Y. - Increased levels of soluble interleukin-2 receptors in Grave's disease. Proceeding of the Eighth International Congress of Endocrinology, Kyoto, July 17-23 1988, p. 267.

85. Colvin RB, Fuller TC, MacKenn L, Kung PC, IP SH, Cosimi AB. - Plasma interleukin-2 receptor levels in renal allograft recipient. Clin Immunol Immunopathol 1987; 43: 273-276.

86. Stole V, Krause JR. - Interleukin-2 receptor levels are increased in blood of heart transplant patients during infections. Diagn Clin Immunol 1987; 43: 273.

87. Wagner DK, Kiwanuka J, Brenda K, Rubin LA, Nelson DL, Magrath IT. - Soluble interleukin-2 receptor levels in patients with undifferentiated and lymphoblastic lymphomas: correlation with survival. J Clin Oncol 1987; 5: 1262-1274.

88. Chilosi M, Pizzolo G, Semenzato G, Cetto G. - Detection 
of a soluble form of the receptor for interleukin-2 in the serum of patients with hairy cell leukaemia. Int J Biol Markers 1986; 1: 101-104.

89. Rovelli F, Lissoni P, Crispino S, et al. - Increased levels of soluble interleukin-2 receptor in advanced solid tumors: a preliminary study. Tumori 1988; 74: 633-637.

90. Lissoni B, Barni S, Rovelli F, et al. - The biologic significance of soluble interleukin-2 receptors in solid tumors. Eur J Cancer 1990; 26: 33-36.

91. Marino P, Cugno M, Preatoni A, et al. - Increased levels of soluble interleukin-2 receptors in serum of patients with lung cancer. Br J Cancer 1990; 61: 434-435.

92. Buccheri GF, Marino P, Preatoni A, Ferrigno D, Moroni G. - Soluble interleukin-2 receptor in lung cancer: an indirect marker of tumor activity? Chest 1991; 99: 1433-1437.

93. Ginns LC, De Hoyos A, Brown MC, Gaumond BR. Elevated concentration of soluble interleukin-2 receptors in serum of smokers and patients with lung cancer. Am Rev Respir Dis 1990; 142: 398-402.

94. NaKajama T, Shimosato Y, Morinaga S, et al. - Immunohistochemical study of small cell carcinoma, with special reference to neuroendocrine markers aromatic L-amino acid decarboxylase and gastrine-releasing peptide. Jpn J Clin Oncol 1986; 16: 223.

95. Said JW, Vimadalal S, Nash G. - Immunoreactive neuronspecific enolase, bombesin, and chromogranin as marker for neuroendocrine lung tumors. Hum Pathol 1985; 16: 236.

96. O'Connor OT, Deftos LJ. - Secretion of chromogranin A by peptide producing endocrine neoplasm. $N$ Engl J Med 1986; 31: 1145.

97. Sobol RE, O'Connor DT, Addison J, Suchocki K, Royston I, Deftos LJ. - Elevated serum chromogranin A concentration in small-cell lung carcinoma. Ann Intern Med 1986; 105: 698-700.

98. Fletcher L, Rider CC, Taylor CB. - Enolase isoenzymes. III. Chromatographic and immunological characteristics of rat brain enolases. Biochim Biophys Acta 1976; 452: 245252.

99. Rider CC, Taylor CB. - Enolase isoenzyme in rat tissues. Electrophoretic, chromatographic, and Kinetic properties. Biochim Biophys Acta 1974; 365: 285-300.

100. Rider CC, Taylor CB. - Evidence for a new form of enolase in rat brain. Biochim Biophys Res Commun 1975; 66: 814-820.

101. Schmechel D, Marangos PJ, Brightman M. - Neuronspecific enolase is a molecular marker for peripheral and central neurendocrine cells. Nature 1978; 276: 834-836.

102. Warton J, Polak JM, Cole GA, Marangos PJ, Pearse AGE. - Neuron-specific enolase as an immunocytochemical marker for the diffuse neuroendocrine system in human fetal lung. J Histochem Cytochem 1981; 29: 1359-1364.

103. Kato K, Ishigoro Y, Ariyoshi Y. - Enolase isozymes as disease markers: Distribution of three enolase subunits $(\alpha$, $\beta, \gamma)$ in various human tissues. Disease Markers 1983; 1 : 213-220.

104. Kato K, Ishigoro Y, Suzuki F, Ito A, Semba R. - Distribution of nervous system-specific forms of enolase in peripheral tissues. Brain Res 1982; 237: 441-448.

105. Kato K, Asai R, Shimizu A, Suzuki F, Ariyoshi Y. Immunoassay of three enolase isoenzymes in human serum and in blood cells. Clin Chim Acta 1983; 127: 353-363.

106. Haimoto M, Takahashi Y, Koshikawa T, Nagura H, Kato K. Immunohistochemical localization of $\gamma$-enolase in normal human tissues other than nervous and neuroendocrine tissues. Lab Invest 1985; 52: 257-263.

107. Carney DN, Ihde DC, Cohen MH, et al. - Serum neuronspecific enolase: a marker for disease extent and response to therapy of small cell lung cancer. Lancet 1982; 1 : 583-585.

108. Ariyoshi Y, Kato K, Ishiguro Y, Sato T, Suchi T. Evaluation of serum neuron-specific enolase as a tumor marker for carcinoma of the lung. Gann 1986; 74: 219.

109. Cooper EH, Splinter TAW, Broun DA, et al. - Evaluation of a radioimmunoassay for neuron specific enolase in small cell lung cancer. Br J Cancer 1985; 52: 333-338.

110. Esscher T, Steinholtz L, Bergh Nou E, Nilsson K, Pahlman S. - Neuron specific enolase: a useful diagnostic serum marker for small cell carcinoma of the lung. Thorax 1985; 40: 85-90.

111. Johnson DH, Marangos PJ, Forbes JT et al. - Potential utility of serum neuron-specific enolase levels in small cell carcinoma of the lung. Cancer Res 1984; 44: 5409.

112. Akoun GH, Scarna HM, Milleron BJ, Benichou MP, Herman DP. - Serum neuron specific-enolase. A marker for disease extent and response to therapy for small cell lung cancer. Chest 1985; 37: 39-43.

113. Splinter TAW, Cooper EH, Kho GS, Oosterom R, Peake MO. - Neuron-specific enolase as a guide to the treatment of small cell lung cancer. Eur J Cancer Clin Oncol 1987; 2: $171-175$.

114. Jorgensen LG, Hirsh FR, Osterlind K, Cooper EH, Larsson LI. - Occurrence of neuron-specific enolase in tumour tissue and serum in small cell lung cancer. $B r J$ Cancer 1991; 63: 151-153.

115. Harding M, McAllister J, Hulks G, et al. - Neuron-specific enolase (NSE) in small cell lung cancer: a tumour marker of prognostic significance? Br J Cancer 1990; 61: 605-607.

116. Jaques G, Bepler G, Holle R, et al. - Prognostic value of carcinoembryonic antigen, neuron-specifc enolase, and creatinine Kinase-BB levels in sera of patients with small cell lung cancer. Cancer 1988; 62: 125-134.

117. Viallard JL, Caillaud D, Kantelip B, Molina C, Dastugue B. - Enzymatic determination of serum neuron-specific enolase in small cell lung cancers. Utility of the serum neuronspecific enolase serum/nonneuronal enolase ratio. Chest 1988; 93: 1225-1233.

118. Gazdar AF, Zweig MH, Carney DN, Van Steirteghen AC, Baylin SB, Minna JD. - Levels of creatine Kinase and its BB isoenzyme in lung cancer specimens and cultures. Cancer Res 1981; 41, 2773-2777.

119. Weynants P, Humblet Y, Canon JL, Symann M. Biology of small cell lung cancer: an overview. Eur Respir J 1990; 3: 699-714.

120. Gazdar AF, Carney DN, Nau MM, Minna JD. - Characterization of variant subclasses of cell lines derived from small cell lung cancer having distinctive biochemical, morphological, and growth properties. Cancer Res 1985; 45: 2924-2930.

121. Carney DN, Zweig MH, Ihde DC, Cohen MH, MaKuch RW, Gazdar AF. - Elevated serum creatine Kinase BB levels in patients with small cell lung cancer. Cancer Res 1984; 44: 5399-5403.

122. Bork E, Hansen M, Urdal P, et al. - Early detection of response in small cell bronchogenic carcinoma by changes in serum concentrations of creatine kinase, neuron-specific enolase, calcitonin, ACTH, serotonin and gastrin-releasing peptide. Eur J Cancer Clin Oncol 1988; 24: 1033-1038.

123. Pedersen AG, Bach FW, Nissen M, Bach F. - Creatine Kinase $\mathrm{BB}$ and beta--microglobulin as markers of CNS metastases in patients with small-cell lung cancer. J Clin Oncol 1985; 3: 1364-1372.

124. Spiro RG. - Glycoproteins. Ann Rev Biochem 1970; 39: 599-638.

125. Podolsky DK, Weiser MM. - Galactosyltransferase 
activities in human sera: detection of a cancer-associated isoenzyme. Biochem Biophys Res Commun 1975; 65: 545551.

126. Gazinger U, Deutsch E. - Serum sialyltransferase levels as a parameter in the diagnosis and follow-up of gastrointestinal tumors. Cancer Res 1980; 40: 1300-1304.

127. Davery RA, Milliken ST, Harvie RM, et al. - Serum galactosyltransferase as a prognostic marker in patients with solid tumors. Cancer Res 1986; 46: 5973-5975.

128. Yazawa S, Madiyalakan R, Izawa H, Asao T, Furukawa K, Matta KL. - Cancer-associated elevation of a-(1-3)-Lfucosyltransferase activity in human serum. Cancer 1988; 62: 516-520.

129. Holmes EH, Ostrander GK, Hakomori S. - Enzymatic basis for the determination of glycolipids with $\chi$ and dimeric $\chi$ determinants in human lung cancer cell (NCI-H69). J Biol Chem 1985: 260: 7619-7622.

130. Holmes EH, Ostrander GK, Hakomori S. - Biosynthesis of the sialyl-Lex determinant carried by type 2 chain glycosphingolipids $\left(\mathrm{IV}^{3} \mathrm{NeuAcIII}{ }^{3} \mathrm{FucnLc}_{4}, \mathrm{VI}^{3} \mathrm{NeuAcV}{ }^{3}\right.$ FucnLc 6 , and $\mathrm{VI}^{3} \mathrm{NeuAcIII}^{3} \mathrm{~V} \mathrm{Fu}_{2} \mathrm{cnLc}_{6}$ ) in human lung carcinoma PCs cells. J Biol Chem 1986; 261: 3737-3743.

131. O'Connor GI, Tatarinov YS, Abelev GI, Uriel J. - A collaborative study for the evaluation of a serological test for primary liver cancer. Cancer 1970; 25: 1091-1098.

132. Kannagi R, Fukushi Y, Tachikawa T, et al. - Quantitative and qualitative characterization of human cancer-associated serum glycoprotein antigens expressing fucosyl or sialylfucosyl type 2 chain polylactosamine. Cancer Res 1986; 46: 2619-2626.

133. Ronquist G, Nou AE. - Serum sialyltransferase and fucosyltransferase activities in patients with bronchial carcinoma. Cancer 1983; 52: 1679-1683.

134. Asao T, Yazawa S, Nagamachi Y, et al. - Serum a (1-3)-L-fucosyltransferase, carcinoembryonic antigen, and sialyl Lewis $\chi$-i antigen levels in lung cancer. Cancer 1989; 64: 2541-2545.

135. Anastasi A, Erspamer V, Bucci M. - Isolation and structure of bombesin and alytesin, two analogous active peptides from the skin of the European frogs Bombina and Alytes. Experientia 1971; 27: 166-167.

136. Wharton J, Polak JM, Bloom SR, et al. - Bombesin-like immunoreactivity in the lung. Nature 1978; 273: 769-770.

137. Ghatei MA, Sheppard MN, Henzen-Logman S, et al. Bombesin and vasoactive intestinal polypeptide in the developing lung: marked changes in acute respiratory distress syndrome. J Clin Endocrinol Metab 1983; 57: 1226-1232.

138. Polak JM, Ghatei MA, Wharton J, et al. - Bombesin-like immunoreactivity in the intestinal tract, lung and central nervous system. Scand J Gastroenterol 1978; 13 (Suppl.): 148.

139. Yagamuchi K, ABE K, Kameya T, et al. - Production and molecular size heterogeneity of immunoreactive gastrinreleasing peptide in fetal and adult lungs and primary lung tumours. Cancer Res 1983; 43: 3932-3938.

140. Moody TW, Berthness V, Carney DN. - Bombesin-like peptides and receptors in human tumour cell lines. Peptides 1983; 4: 683-686.

141. Carney DN, Cuttitta F, Moody TW, et al. - Selective stimulation of small cell lung cancer clonal growth by bombesin and gastrin-releasing peptide. Cancer Res 1987; 47: 821-825.

142. Sorensen GD, Bloom SR, Ghatei MA, et al. - Bombesin production by human small cell carcinoma of the lung. Regul Pept 1982; 4: 59-66.

143. Scagliotti GV, Piani M, Gatti E, et al. - Combined measurement of neuron-specific enolase and bombesin/gastrin releasing peptide in lung cancer. Eur Respir $J$ 1989; 2: 746-748.

144. Cuttitta F, Carney DN, Mulshine J, et al. - Bombesin-like peptides can function as autocrine growth factors in human small-cell lung cancer. Nature 1985; 316: 823-826.

145. Holst JJ, Hansen M, Bork E, et al. - Elevated plasma concentrations of GRP c-flaning peptide in small cell lung cancer. (In preparation).

146. Pedersen AG, Becker KL, Bach F, et al. - Cerebrospinal fluid bombesin and calcitonin in patients with central nervous system metastases from small cell lung cancer. J Clin Oncol 1986; 4: 1620-1627.

147. Brown WH. - A case of pluriglandular syndrome: "Diabetes of bearded women". Lancet 1928; 215: 1022 1023.

148. Azzopardi JG, Williams ED. - Pathology of nonendocrine tumors associated with Cushing's syndrome. Cancer 1968; 22: 274-286.

149. Blackman MR, Rosen SW, Weintraub BD. - Ectopic hormones. Adv Intern Med 1978; 23: 85-113.

150. Yalow RS, Eastridge CE, Higgins G, et al. - Plasma and tumor ACTH in carcinoma of the lung. Cancer 1979; 44: 1789-1792.

151. Hansen M, Hansen HH, Hirsch FR, et al. - Hormonal polypeptides and amine metabolites in small cell carcinoma of the lung, with special reference to stage and subtypes. Cancer 1980; 45: 1432-1437.

152. Ratcliffe JC, Podmose J, Stack BH, et al. - Circulating ACTH and related peptides in lung cancer. Br J Cancer 1982; 45: 230-236.

153. Azzopardi JC, Freeman E, Poole G. - Endocrine and metabolic disorders in bronchial carcinoma. $\mathrm{Br}$ Med $\mathrm{J}$ 1970; 4: 528-589.

154. Bondy PK, Gilby ED. - Endocrine function in small cell undifferentiated carcinoma of the lung. Cancer 1982; 50: 2147-2153.

155. Hansen M, Hammer M, Hummer L. - Diagnostic and therapeutic implications of ectopic hormone production in small cell carcinoma of the lung. Thorax 1980; 35: 101-106.

156. Lokich JJ. - The frequency and clinical biology of the ectopic hormone syndromes of small cell carcinoma. Cancer 1982; 50: 2111-2114.

157. Rassam JW, Anderson C. - Incidence of paramalignant disorders in bronchogenic carcinoma. Thorax 1975; 30: 86-90.

158. Hansen M, Hammer M, Hummer L. - ACTH, ADH and calcitonin concentrations as markers of response and relapse in small cell carcinoma of the lung. Cancer 1980; 46: 2062-2067.

159. Chan JSD, Seidah NG, Chretien M. - Human $\mathrm{NH}_{2}$ terminal of pro-opiomelanocortin as a potential marker for pulmonary carcinoma. Cancer Res 1983; 43: 3066-3069.

160. Winkler AW, Crankshaw OF. - Chloride depletion in conditions other than Addison's disease. J Clin Invest 1938; 17: $1-6$.

161. Schwartz WB, Bennet W, Curelop S, et al. - A syndrome of renal sodium loss and hyponatremia probably resulting from inappropriate secretion of antidiuretic hormone. Am J Med 1957; 23: 529-542.

162. George JM, Capen CC, Phillips S. - Biosynthesis of vasopressin in vitro and ultrastructure of a bronchogenic carcinoma. Patient with the syndrome of inappropriate secretion of antidiuretic hormone. J Clin Invest 1972; 51: 141-148.

163. Ewing HP, Newsom BD, Hardy JD. - Tumor markers. Curr Probl Surg 1982; 19: 56-94.

164. Hansen M. - Clinical implications of ectopic hormone 
production in small cell carcinoma of the lung. Dan Med Bull 1981; 28: 221-236.

165. Greco AF, Hainsworth J, Sismann A. - Hormone production and paraneoplastic syndromes. In: Greco AF, Oldham RK, Bunn PA eds. Small Cell Lung Cancer. New York, Grune \& Stratton, 1981; pp. 177-224.

166. Gropp C, Luster W, Havemann K, Lehmann FG. $\mathrm{ACTH}$, calcitonin, alfa-MSH, beta-endorphin, parathormone and beta-hCG in sera of patients with lung cancer. In: Uhlenbruk G, Wintzer G, eds. CEA und andera Tumormarker. Leomberg, Tumor Diagnostik Verlag, 1981; pp.358-363.

167. Haefliger JM, Dubied MC, Vallotou MB. - Excretion journaliere de l'hormone antidiuretique lors de carcinome bronchique. Schweiz Med Wochenschr 1977; 107: 726-732.

168. North WG, Maurer H, Valtin H, O'Domell JF. - Human neurophysins as potential tumor markers for small cell carcinoma of the lung: application of specific radioimmunoassays. J Clin Endocrinol Metab 1980; 51: 892-897.

169. Hainsworth JD, Workmann R, Greco FA. - Management of the syndrome of inappropriate antidiuretic hormone secretion in small cell lung cancer. Cancer 1983; 51: 161-165.

170. Maurer LH, O'Domell JF, Kennedy S, et al. - Human neurophysins in carcinoma of the lung: relation to histology, disease state, response rate, survival, and syndrome of inappropriate anti-diuretic hormone secretion. Cancer Treat Rep 1983; 67: 971-976.

171. Dilley WG, Wells SA, Cooper CW. - Calcitonin radioimmunoassay. In: Rose NR, Friedman $\mathrm{H}$, eds. Manual of Clinical Immunology, 2nd. edn. Washington, DC, American Society of Microbiology, 1980; pp. 944-950.

172. Heynen G, Franchimont P. - Human calcitonin radioimmunoassay in normal and pathological conditions. Eur $J$ Clin Invest 1974: 4: 213-222.

173. De Lellis RA, Rule AH, Spiler I, et al. - Calcitonin and carcinoembrionic antigen as tumor markers in medullary thyroid carcinoma. Am J Clin Pathol 1978; 70: 587-594.

174. Coombes RC, Greenberg PB, Hillyard C, et al. - Plasma immunoreactive calcitonin in patients with non-thyroid tumors. Lancet 1974; 1: 1080-1081.

175. Bierbaum W, Hutoma T, Niederle N, et al. - Calcitonin in monitoring patients with small cell carcinoma of the lung during chemotherapy. Cancer Detect Prev 1982; 25: 258.

176. Greco FA, Sismani A, Hande K, et al. - Plasma calcitonin and antidiuretic hormone (ADH) as markers in small cell lung cancer. Proc Am Assoc Cancer Res 1981; 22: 342.

177. Luster W, Gropp C, Sostmann H, et al. - Demonstration of immunoreactive calcitonin in sera and tissues of lung cancer patients. Eur J Cancer Clin Oncol 1982; 18: 1275-1283.

178. McKenzie CG, Evans IMA, Hillyard CJ, et al. - Biochemical markers in bronchial carcinoma. Br J Cancer 1977; 36: 700-707.

179. Sappino AP, Ellison ML, Carter SC, et al. - Correlation of 3 tumor markers (calcitonin, CEA, and beta-hCG) with response to therapy and extent of disease in small cell lung cancer. Br J Cancer 1981; 44: 300.

180. Wallach SR, Royston I, Taetle R, et al. - Plasma calcitonin as a marker of disease activity in patients with small cell carcinoma of the lung. J Clin Endocrinol Metab 1981; 53: 602-606.

181. Roos BA, Lindall AW, Baylin SB, et al. - Plasma immunoreactive calcitonin in lung cancer. $J$ Clin Endocrinol Metab 1980: 50: 659-666.

182. Mulder H, Hackeng WHL, Silberbusch J, et al. - Value of serum calcitonin estimation in clinical oncology. $\mathrm{Br} J$ Cancer 1981; 43: 786-792.

183. Humbel RE. - Insulin-like growth factors, somato-medins, and multiplication stimulating activity: chemistry. In: $\mathrm{Li}$ $\mathrm{CH}$ ed. Hormonal Proteins and Peptides. New York, Academic Press, vol. 12. 1984; pp. 57-79.

184. Ullrich A, Gray A, Tam AW, et al. - Insulin-like growth factor-I receptor primary structure: comparison with insulin receptor suggests structural determinants that define functional specificity. EMBO J 1986; 5: 2503-2512.

185. Morgan OD, Edman JC, Standring DN, et al. - Insulinlike growth factor-II receptor as a multifunctional binding protein. Nature 1987; 329: 301-330.

186. Macauly VM, Teale JD, Everard MJ, Joshi GP, Millar JL. - Somatomedin-C/insulin-like growth factor-I is a mitogen for human small cell lung cancer. Br J Cancer 1988; 57: 91-93.

187. Macauly VM, Teale JD, Everard MJ, Joshi GP, Millar JL, Smith IE. - Serum insulin-like growth factor-I levels in patients with small cell lung cancer. J Cancer Clin Oncol 1988; 24: 1241-1242.

188. Reeve JG, Payne JA, Bleehen NM. - Production of immunoreactive insulin-like growth factor-I (IGF-I) and IGF-I binding proteins by human lung tumours. $B r J$ Cancer 1990; 61: 727-731.

189. Crofton J. - Tobacco and third world. Thorax 1990; 45: 164-169.

190. Hirsch FR, Ottesen G, Podenphant J, Olsen J. - Tumor heterogeneity in lung cancer based on light microscopic features. A retrospective study of a consecutives series of 200 patients, treated surgically. Virch Arch (Pathol Anat) 1983; 402: 147-156.

191. Matthewes MJ. - Effects of therapy on the morphology and behaviour of small cell carcinoma of the lung. A clinico-pathologic study. In: Muggia F, Rozenweig M, eds. Lung Cancer: Progress in Therapeutic Reserch. New York, Raven Press, 1977; pp. 155-165.

192. Brereton HD, Mathwes MN, Costa J, Kent CH, Johnson RE. - Mixed anaplastic small cell and squamous cell carcinoma of the lung. Ann Inter Med 1978; 88: 805-806.

193. Abeloff MD, Eggleston JC, Mendelsohn G, Ettinger DS, Baylin SB. - Changes in morphologic and biochemical characteristics of small cell carcinoma of the lung. Am J Med 1979; 66: 754-764.

194. Sehested M, Hirsch FR, Osterlind K, Olsen JE. Morphologic variations of small cell lung cancer. A histopathologic study of pretreatment and posttreatment specimens in 104 Patients. Cancer 1986; 57: 804-807.

195. Terasaki T, Shimosato Y, Nakajama T, et al. - Reversible squamous cell characteristics induced by vitamin A deficiency in a small cell lung cancer cell line. Cancer Res 1987; 47: 3533-3537.

196. Carney DN, Gazdar AF, Bepler G, et al. - Establishment and identification of small cell lung cancer cell lines having classic and variant features. Cancer Res 1985; 45: 29132923.

197. Gazdar AF, Carney DN, Nau M, Minna JD. - Characterization of variant subclasses of cell lines derived from small cell lung cancer having distinctive biochemical, morphological and growth properties. Cancer Res 198S; 45: 2923-2927.

198. Stahel RA, Ginsberg R, Havemann K, et al. - Staging and prognostic factors in small cell lung cancer: a consensus report. Lung Cancer 1989; 5: 119-126. 